\title{
Banks Intermediation and Stock Prices of Deposit Money Banks in Nigeria: VECM and Variance Decomposition Approach
}

\author{
Subair K.*1, Soyebo Yusuf $\mathrm{A}^{2}$ \\ ${ }^{1}$ Olabisi Onabanjo University, Ago-Iwoye, Ogun State, Nigeria \\ ${ }^{2}$ Lagos State University, Ojo
}

\begin{abstract}
This study adopts the Vector Error Correction Model (VECM) and the variance decomposition techniques in testing the financial acceleration theory in banks intermediation. The bank intermediation variable is categorized into variable deposit mobilization, loan administration, delegated monitoring and risk diversification. Using cointegration analysis and quarterly secondary data between 2009 and 2016, this study assessed the short and long run influence of the categorized bank activities on their stock prices. The results indicate that banks intermediation exact influence on both the short and long run stock prices of DMBs in Nigeria as the ECM (-0.1420) result showed a significant speed of adjustment towards equilibrium while the overall model fitness showed that there is a long run causality running from banks intermediation measures and stock prices. Similarly, the result of the variance decomposition of stock prices shocks indicate that over time a significantly increasing proportion of stock prices is explained by loans and capital (delegated monitoring).
\end{abstract}

\section{Introduction}

The 2008/2009 financial crisis in Nigeria stemmed from the ripple effect of the 2007/2008 global financial crisis which created a transmissible shock across various sectors of the world economies. The crisis arose from the financial sectors failure transmitted to the rest of the economy and created problems such as investment fluctuation and credit policy contraction that worsened transactions in trading for all economies and consequently created a chain of crisis that threatened the entire financial sector.

Consequently, stock markets activities dropped substantially due to accumulative bank lending exposure to various industries and natural bank hazard in the years preceding the crisis as various market collapses spread to the financial region. The downturns in the financial markets reduced investors' assurance and together with the contraction in bank loans, affected the manufacturing industries. By the middle of 2009, most economies suffered drastically resulting in decreased level of economic activities as the real value of wealth and assets of most market participants have been massively eroded.

The financial crisis resuscitated studies on several issues such as banks shock transmission, financial pollution, stock return estimation and market efficiency hypotheses. Though, some

*Corresponding author.

Email: kolasubair@gmail.com 
studies focused on these issues (Adrian and Shin, 2010; Karkowska, 2013; Tennant and Tracey, 2014); an aspect which has received less attention is study on the influence of financial intermediation on stock price of Deposit Money Banks (DMBs) in Nigeria. This aspect is important due to the need to have an informed understanding of the banking sector features, its reflection and transmission to stock prices as well as shocks dissemination process in the economy.

Also, the downward trend in the economy can influence DMBs intermediation functions in terms of decline in the size of deposit and loans which, in turn, can adversely affect DMBs' stock price and expose them to default risks. With the various attentions given to DMBs and stock markets all over the world after the financial crisis, the dynamic relations between banks financial intermediation and stock prices warrant further empirical investigation at the industry and firm level in Nigeria given its role as the centre piece of commerce in sub-Saharan Africa.

\section{Literature Review}

Several studies have analysed banks' intermediation due to its significant role in facilitating liquidity and project financing through the channelization and transmission of financial resources among competing units in the economies. While most literature examined their influence on economic growth, fewer studies considered the financial intermediation influence on stock prices of DMBs. Ibrahim (2006) examined the nature of interactions of bank loans and stock prices in order to explain the role played by bank loans vis--vis financial surges in the economy using quarterly data between 1978 and 1988 in Malaysia. The result revealed that KLCI, GDP and INT have positive and significant influence on bank loans but there is no counter reaction from bank loans. In relation to the foregoing is that, Tennant \& Tracey (2014) had examined how banks core functions impact stock market fluctuation in Jamaica using an unconditional descriptive measure of realized volatility and Generalized Autoregressive Conditional Heteroskedasticity (GARCH) specification on quarterly data. Such data include deposit to asset, loan to asset, ratio of credit to private sector to loans, spread, liquid asset ratio in a simple autoregression with exogenous variables (ARX). All the explanatory variables and their lags are put through a loop of pairwise granger causality tests to determine which variables (and at what specific lags) significantly improve the forecast of stock market volatility. The results showed that factors which affect banks' profitability can increase stock market volatility.

Similarly, Francis et al. (2015) examined the influence of regulation and supervision on the returns to bank stock using specific fundamentals with stock price informativeness. Using selected countries, the study adopted two approaches and the result of the logistic OLS regression estimates showed that stock returns are not rapidly adjusted in countries with strict capital control, adequate supervision and low state investments in banks while Shabib-ul Hasan and Muhammad (2015) examined the most effective financial variable (debt-equity ratio, book to market value and firm size) in explaining stock prices using twenty six companies selected from pharmaceutical and chemical sector in Karachi Stock Exchange between 2000 and 2009. Regression results revealed that book to market value of equity is the most effective indicator.

Anwaar (2016) checked the influence of firm results on stock returns in London Stock Exchange between 2005 and 2014 using a panel regression specification. The analytical result showed that net profit margin and return on assets had positive and significant influence on stock returns while earnings per share had negative influence on stock returns. Kühl (2017) examined the advancement in bank capital based on the proportion of non-state-contingent assets in their statement of financial position and implications for general economic changes 
using a new Keynesian dynamic general equilibrium model. The results showed that shocks' transmission to real GDP is created by banking sector frictions that reduced as the size of nonstate-contingent assets increases. The study revealed that a mixture of assets in bank financial position is key to increasing shocks in financial contract as they are signed before the emergence of shocks and their repayment is assured with protection of the banks' balance sheets.

Blau et al. (2017) examined opacity and its nature within firms as well as its influence on stock prices efficiency, focusing analysis on banks due to their opaqueness than other firms. They explored how bank prices incorporate market-wide information and reflect firm efficiency using firm-specific information, multivariate time-series analysis and vector auto regressive (VAR) process. The study captured stock prices inefficiency and found evidence supporting that opacity is positively related to price delay.

\section{Methodology}

The study employed industrial level quarterly secondary data from all quoted DMBs in Nigeria for the period of 2009-2016. The data were obtained from Nigerian Stock Exchange (NSE). The study examined the dynamic relationships between banks intermediation and stock prices using DMBs variables such as banking stock index, deposit mobilization, loans administration, delegated monitoring and risk diversification. The mathematical equation for estimating the relationship between banks intermediation and stock prices of DMBs in Nigeria is derived from the financial accelerator general equilibrium model by Gilchrist and Zakrajšek (2011). According to the BGG (1999) model, there are set of financial intermediaries (DMBs) that attract savings $\left(S_{t}\right)$ in form of deposit, with an initial capital $\left(C_{t}\right)$ in order to generate new fund $\left(C_{t+1}\right)$ part of which can be granted as loan and advances to investors based on the subsequent identical technology equation stated as:

$$
C_{t+1}=\Phi\left(\frac{S_{t}}{C_{t}}\right) C_{t}+(1-\delta) C_{t}
$$

where $\Phi($.$) is an increasing and concave adjusted cost function that depends on the ratio$ of investment and capital while $\delta$ is the depreciation rate of capital. Once a loan is repaid, it is channeled through the DMBs. Thus, there are two important prices, the new capital $Q_{t}$ and previous capital $\bar{Q}_{t}$. Similarly, the DMBs attract used capital at a price $\bar{Q}_{t} S_{t}$, invests $S_{t}$ and sells new capital for a revenue of $Q_{t} C_{t+1}$.

Hence, the economic problem facing DMBs is how to maximize the excess or difference between the two prices given as:

$$
\begin{gathered}
\max _{K_{t} I_{t}} Q_{t} C_{t+1}-S_{t}-\bar{Q}_{t} S_{t} \\
\text { s.t. } C_{t+1}=\Phi\left(\frac{S_{t}}{C_{t}}\right) C_{t}+(1-\delta) S_{t}
\end{gathered}
$$

The optimality condition for equation (3) is calibrated into two equilibrium prices as follows: 


$$
\begin{gathered}
Q_{t}=\left(\Phi^{\prime}\left(\frac{S_{t}}{C_{T}}\right)\right)^{-1} \\
\bar{Q}_{t}=\left[(1-\delta)+\Phi\left(\frac{S_{t}}{C_{t}}\right)-\Phi^{\prime}\left(\frac{S_{t}}{C_{T}}\right) \frac{S_{t}}{C_{T}}\right] Q_{t}
\end{gathered}
$$

The BGG model is derived in equation (5) but the price of DMBs existing capital is different from that of the BGG and by introducing $\bar{Q}_{t}$ into the model, to serve as the BGG price on existing capital, the zero-profit condition is derived as:

$$
Q_{t} \Phi\left(\frac{S_{t}}{C_{t}}\right) C_{t}+Q_{t} C_{t}-S_{t}-Q_{t} S_{t}=0
$$

which can also be restated as:

$$
\bar{Q}_{t}=Q_{t} \Phi\left(\frac{S_{t}}{C_{t}}\right)-\left(\frac{S_{t}}{C_{t}}\right)+Q_{t}
$$

Similarly, the strength of a DMBs to withstand operational shocks and market competition is a function of its capital $\left(C_{t}\right)$ and asset $\left(A_{t}\right)$. However, due to the nature of new fund (deposit), the DMBs are compelled by law to withhold certain fraction $\left(R_{t}\right)$ against unanticipated withdrawal. This reduced the size of available fund for lending and yield loan size $L_{t}=\left(C_{t}-R_{t}\right)$.

Thus, attaining the maximization objective in equation (2) depends on other endogenous factors and by injecting them into the model, it will yield a normalized equation stated as:

$$
P=\left(Q_{t} S_{t}, S_{t}, \bar{Q}_{t} C_{t}, L_{t}, A_{t}, C_{t}\right)
$$

where

$\mathrm{P}=$ Profit

$Q_{t} S_{t}=$ Cost of used capital

$S_{t}=$ Savings or Deposits

$\bar{Q}_{t} C_{t}=$ Revenue from the sales of new capital

$L_{t}=$ Loans and advance

$A_{t}=$ Asset

Equally, DMBs activities usually affect the aggregate economic conditions due to their roles as a key financial intermediary and using $\pi_{t}$ to represent the difference between lending and deposit rate (spread). The equation (8) can be linearized as:

$$
P=\left(S_{t}, L_{t}, A_{t}, C_{t}, \pi_{t}\right)
$$

Where:

$\mathrm{P}=$ Stock prices

$S_{t}=$ Deposits 
$L_{t}=$ Loans and advance

$A_{t}=$ Asset

$C_{t}=$ Capital

$\pi_{t}=$ Spread

Equation (9) form the base line equation for this study and other control variables that can influence stock prices are incorporated in line with evidence from literature.

\subsection{Estimation Procedure}

\subsubsection{Unit Root Test}

The quarterly data set were exposed to unit root tests using the Augmented Dickey Fuller (ADF) and Phillips-Perron (PP) to show whether the variables are stationary or not.

\subsubsection{Multivariate Approach Tests}

The study embraces the Johansen's cointegration test (Johansen, 1991) specification which is embedded in the Vector Autoregression (VAR) of order $\mathrm{p}$ was used to test for cointegration

\subsubsection{The Vector Error Correction (VEC) Model}

The VEC model which is a restricted VAR model is designed for analysing non-stationary cointegrated series with an in built cointegration relations specification in order to monitor endogenous variables long run relation towards cointegration convergence while providing for short-run dynamics adjustment. The error correction term signifies the cointegration coefficient because long term equilibrium deviations are corrected gradually through series of partial shortrun adjustments.

Thus, the VEC model for estimating the relationship between banks intermediation and stock prices of DMBs in Nigeria is stated as:

$$
\begin{aligned}
& \Delta \text { Index }=\propto+\sum_{i=1}^{m} \beta i \Delta \text { Index }_{i-1}+\sum_{j=1}^{n} \text { ridIndep }_{i-j}+\sum_{k=1}^{o} \delta \Delta \text { Inloans }_{i-j} \\
& +\sum_{l=1}^{p} \zeta \Delta \text { Incapital }+\sum_{m=1}^{q} \zeta \Delta \text { Inasset }+ \\
& +\sum_{l=1}^{p} \zeta \Delta \text { Inspread }+\sum_{m=1}^{q} \zeta \Delta \text { Inint }+\sum_{n=1}^{r} \zeta \Delta \text { Inleverage }+\sum_{n=1}^{s} \pi \Delta \text { InState }+\theta Z_{t-1}+\varepsilon_{t}
\end{aligned}
$$

where:

Index $=$ Natural log of Banking Index

Indep $=$ Natural log of Bank deposits

Inloans $=$ Natural log of Bank loans

Incapital $=$ Natural log of Bank capital

Inasset $=$ Natural log of Bank asset

Inspread $=$ Natural log of Bank spread

Inint $=$ Natural $\log$ of interest rate

Inleverage $=$ Natural log of Bank leverage

InState $=$ State of economy

$Z_{t-1}=$ the error-correction term 


\section{Results and Discussions}

The results from the Augmented Dickey-Fuller (ADF) and Philips-Perron (PP) Unit Root Test for the study are presented in tables 1 and 2 below:

Table 4.1: Augmented Dickey-Fuller (ADF) Unit Root Results

\begin{tabular}{lcccccc}
\hline Variables & Level & Prob. & Critical Values & First Difference & Prob. & Critical Values \\
\hline BANKING_INDEX & -2.6603 & 0.0923 & -2.9604 & -7.7885 & 0.0000 & -2.9639 \\
DEPOSITS & -1.3454 & 0.5956 & -2.9604 & -5.3347 & 0.0001 & -2.9677 \\
LOANS & 0.2836 & 0.9735 & -2.9604 & -5.6777 & 0.0001 & -2.9639 \\
CAPITAL & -1.0750 & 0.7129 & -2.9604 & -4.9149 & 0.0006 & -2.9918 \\
ASSET & -0.3305 & 0.9090 & -2.9604 & -5.3006 & 0.0002 & -2.9718 \\
SPREAD & -0.9154 & 0.7697 & -2.9604 & -6.9956 & 0.0000 & -2.9639 \\
INTEREST_RATE & 0.6585 & 0.9891 & -2.9604 & -3.8482 & 0.0065 & -2.9639 \\
LEVERAGE & -0.8495 & 0.7905 & -2.9604 & -6.2233 & 0.0000 & -2.9639 \\
ECONOMY OF STATE & -5.1386 & 0.0523 & -2.9604 & -6.5724 & 0.0000 & -2.9718 \\
\hline
\end{tabular}

Source: Author's Computation

Table 4.2: Philips-Perron (PP) Unit Root Results

\begin{tabular}{lcccccc}
\hline Variables & Level & Prob. & Critical values & First Difference & Prob. & Critical Values \\
\hline BANKING_INDEX & -2.7372 & 0.0793 & -2.9604 & -8.3854 & 0.0000 & -2.9640 \\
DEPOSITS & -3.0395 & 0.0422 & -2.9604 & -5.6722 & 0.0001 & -2.9640 \\
LOANS & 0.2836 & 0.9735 & -2.9604 & -5.6770 & 0.0001 & -2.9640 \\
CAPITAL & -1.2807 & 0.6257 & -2.9604 & -4.2510 & 0.0024 & -2.9640 \\
ASSET & 0.0147 & 0.9530 & -2.9604 & -9.2530 & 0.0000 & -2.9640 \\
SPREAD & -0.8313 & 0.7960 & -2.9604 & -7.2670 & 0.0000 & -2.9640 \\
INTEREST_RATE & 0.4929 & 0.9837 & -2.9604 & -3.8373 & 0.0066 & -2.9640 \\
LEVERAGE & -1.4512 & 0.5444 & -2.9604 & -7.9165 & 0.0000 & -2.9640 \\
ECONOMY OF STATE & -5.1311 & 0.0502 & -2.9604 & -18.2222 & 0.0001 & -2.9640 \\
\hline
\end{tabular}

Source: Author's Computation

Table 1 indicates that specified factors in the ADF statistic were stationary at first difference I(1). Table 2 also shows that all the specified variables PP statistic were stationary at first difference I(1). The next stage in the analysis is the cointegration test as a necessary condition for the VECM analysis. Thus, the trace test was used in establishing the number of cointegration relationship among the specified variables and the result are presented in Table 3. 
Table 4.3: Cointegration Rank Trace Results

\begin{tabular}{lccc}
\hline Hypothesized No. of CE(s) & Trace Statistic & Critical Value (0.05) & Prob. $^{* *}$ \\
\hline None * & 264.0275 & 197.3709 & 0.0000 \\
At most 1 * & 196.0047 & 159.5297 & 0.0001 \\
At most 2 * & 139.0029 & 125.6154 & 0.0059 \\
At most 3 & 102.2007 & 95.7536 & 0.0167 \\
At most 4 & 68.1282 & 69.8188 & 0.0677 \\
At most 5 & 38.6209 & 47.8561 & 0.2756 \\
At most 6 & 21.9329 & 29.7970 & 0.3022 \\
At most 7 & 7.2005 & 15.4947 & 0.5545 \\
At most 8 & 0.6730 & 3.8414 & 0.4120 \\
\hline
\end{tabular}

Trace test indicates 4 cointegrating eqn(s) at the 0.05 level

Source: Author's Computation

The result from the trace test supports the null hypothesis rejection since the trace statistics (264.02) exceeds the critical value (197.37) at 95 percent confidence level. This implies that the null hypothesis of no co-integrating relationships is rejected as there are three possible cointegrating equations among the variables at $5 \%$ lag order selection (LOS).

Based on unit root and cointegration results, the study proceeds to the adoption of the VECM estimates through the lag order selection (LOS) criteria which facilitate the selection of the optimum lag. Table 4 presents the results of the VECM LOS.

Table 4.4: VECM Lag Order Selection Criteria Result

\begin{tabular}{cccccc}
\hline Lag & $\begin{array}{c}\text { Sequential } \\
\text { Modified LR test } \\
\text { statistic }\end{array}$ & $\begin{array}{c}\text { Final Prediction } \\
\text { Error (FPE) }\end{array}$ & $\begin{array}{c}\text { Akaike } \\
\text { Information } \\
\text { Criterion (AIC) }\end{array}$ & $\begin{array}{c}\text { Schwarz } \\
\text { Information } \\
\text { Criterion (SIC) }\end{array}$ & $\begin{array}{c}\text { Hannan-Quinn } \\
\text { Information } \\
\text { Criterion (HQ) }\end{array}$ \\
\hline 0 & 56.1204 & $2.27 \mathrm{e}-27$ & -35.8093 & -35.3889 & -35.6748 \\
1 & $240.5716^{*}$ & $3.81 \mathrm{e}-30^{*}$ & -42.4379 & $-38.2343^{*}$ & -41.0931 \\
2 & 72.9072 & $6.79 \mathrm{e}-30$ & $-43.6658^{*}$ & -35.6790 & $-41.1108^{*}$ \\
\hline
\end{tabular}

Note:* indicates lag order

Source: Author's Computation

Table 4 reveals that three out of the five selection criteria favoured lag 1 as indicated by LR, FPE and SIC. Thus, this study adopts lag length 1 for the autoregressive process in the VECM for optimum outcome and completes all the prerequisite tests and requirement for a VECM and the result from the cointegrating equation is in table 5:

Table 5 shows the error correction term of -0.1421 is significant and implies that there is a long-run causality from bank intermediation measures and stock prices with the bank loans being the only variable that exact positive and significant influence on the banking index within the 
Table 4.5: Vector Error Correction Model Result

\begin{tabular}{lcccc}
\hline & Coefficient & Std. Error & t-Statistic & Prob. \\
\hline CointEq1 & -0.1421 & 0.0763 & -1.8625 & 0.0781 \\
BANKING_INDEX(-1) & -0.0189 & 0.1827 & -0.1034 & 0.9187 \\
DEPOSITS(-1) & -0.8622 & 0.8565 & -1.0067 & 0.3267 \\
LOANS(-1) & 0.9506 & 0.4354 & 2.1834 & 0.0417 \\
CAPITAL(-1) & -0.0948 & 0.8365 & -0.1134 & 0.9109 \\
ASSET(-1) & 1.9625 & 4.3554 & 0.4506 & 0.6574 \\
SPREAD(-1) & -1.3138 & 0.8682 & -1.5133 & 0.1467 \\
INTEREST_RATE(-1) & -0.2524 & 2.8007 & -0.0901 & 0.9291 \\
LEVERAGE(-1) & -2.9114 & 3.2458 & -0.8970 & 0.3809 \\
ECONOMY_STATE(-1) & -0.0044 & 0.0142 & -0.3139 & 0.7571 \\
CONSTANT & 0.0048 & 0.0164 & 0.2921 & 0.7734 \\
R ${ }^{2}$ & 0.5783 & F-statistic & 2.6062 \\
2 & 0.3564 & Prob(F-statistic) & 0.0347 \\
S.E. of regression & 0.0549 & Durbin-Watson stat & 2.0439 \\
Sum squared resid & 0.0573 & Log likelihood & 51.347 \\
\hline
\end{tabular}

Source: Author's Computation

period under review. Similarly, the $\mathrm{R}^{2}$ and the ${ }^{2}$ values of 0.5783 and 0.3564 respectively indicate the extent of variations in banking stock index that is attributable to the specified independent variables while standard error of the regression value and the log-likelihood ratio support the assertion with the values of 0.054 and 51.3472 respectively.

The F-statistics value of 2.6062 and its probability value of 0.0347 is significant and lend credence to the overall fitness of the model in explaining the banking stock index while the Durbin-Watson statistics value of 2.0438 showed that there is no autocorrelation in the trend pattern of the specified variables.

A corresponding aspect of the VECM is the Wald short run causality test that checks for short-run relationship among the specified variables. The result of the Wald short-run test is presented in Table 6 below:

Table 6 reveals the Wald t-statistics and f-statistics values as well as their corresponding probabilities for all the specified variables and it shows that only loans had significant relationship with the banking index in the short-run within the period under investigation. Similarly, the residual test results for serial correlation and Heteroskedasticity are presented in the tables below:

Table 7 reveals the Breusch-Godfrey serial correlation f-statistic and observed $\mathrm{R}^{2}$ values with their corresponding probabilities in testing the hypothesis that there is no serial correlation in the specified variables. Both results showed that there is no serial correlation as their probabilities values are greater than 0.05 LOS and thus corroborated the Durbin Watson statistics result 
Table 4.6: Wald short run causality result

\begin{tabular}{lcccc}
\hline Variables & t-statistic & Probability & f-statistic & Probability \\
\hline DEPOSITS(-1) & -1.0067 & 0.3267 & 1.0134 & 0.3267 \\
LOANS(-1) & 2.1835 & 0.0417 & 4.7677 & 0.0417 \\
CAPITAL(-1) & -0.1133 & 0.9109 & 0.0129 & 0.9109 \\
ASSET(-1) & 0.4506 & 0.6574 & 0.2030 & 0.6574 \\
SPREAD(-1) & -1.5132 & 0.1467 & 2.2899 & 0.1467 \\
INTEREST_RATE(-1) & -0.0901 & 0.9291 & 0.0081 & 0.9291 \\
LEVERAGE(-1) & -0.8970 & 0.3809 & 0.8046 & 0.3809 \\
ECONOMY_STATE(-1) & -0.3139 & 0.7571 & 0.0985 & 0.7571 \\
CONSTANT & 0.2921 & 0.7734 & 0.0853 & 0.7734 \\
\hline
\end{tabular}

Source: Author's Computation

Table 4.7: Breusch-Godfrey Serial Correlation LM Result

\begin{tabular}{lccc}
\hline F-statistic & 0.297554 & Prob. F(1,18) & 0.5921 \\
Obs $^{*} R^{2}$ & 0.487858 & Prob. Chi-Square(1) & 0.4849 \\
\hline
\end{tabular}

Source: Author's Computation

discussed earlier in Table 5.

Table 4.8: Heteroskedasticity Test: Breusch-Pagan-Godfrey Result

\begin{tabular}{lccc}
\hline F-statistic & 0.683939 & Prob. F(18,11) & 0.7710 \\
Obs $^{*} R^{2}$ & 15.84354 & Prob. Chi-Square(18) & 0.6035 \\
Scaled explained SS & 4.504004 & Prob. Chi-Square(18) & 0.9994 \\
\hline
\end{tabular}

Source: Author's Computation

Table 8 reveals the f-Statistic and corresponding probabilities for the Breusch-Pagan-Godfrey heteroskedasticity test with the hypothesis that there is no heteroskedasticity in the data series employed in the analysis. All the F-statistics value of 0.6939 showed that there is no heteroskedasticity in the variables distribution and this is confirmed by the probabilities value of 0.7710 .

Table 9 reveals that in the short-run, the changes in the index are attributed to shocks in factors such as the state of the economy and spread. But in the long run, the influence of these factors reduced significantly while loans, capital and interest rate gather great momentum over time as they significantly influence banking index shock within the period under review. 
Table 4.9: Variance Decomposition Result

Variance Decomposition of Index: Index

\begin{tabular}{lcccccccccc}
\hline Period & S.E. & Index & Deposits & Loans & Capital & Asset & Spread & Int. Rate & Leverage & State \\
\hline 1 & 0.0549 & 100.00 & 0.0000 & 0.0000 & 0.0000 & 0.0000 & 0.0000 & 0.0000 & 0.0000 & 0.0000 \\
2 & 0.0791 & 79.335 & 1.0520 & 1.3912 & 1.2119 & 0.1320 & 4.1275 & 0.4153 & 3.8013 & 8.5336 \\
3 & 0.0938 & 74.975 & 1.6298 & 3.3553 & 0.8625 & 0.1733 & 3.1601 & 6.8229 & 2.8115 & 6.2095 \\
4 & 0.1019 & 73.165 & 3.0887 & 4.5755 & 1.1991 & 0.1472 & 2.685636 & 6.9867 & 2.7714 & 5.3812 \\
5 & 0.1125 & 70.502 & 4.6876 & 5.8422 & 2.3967 & 0.5694 & 2.932266 & 6.0449 & 2.3947 & 4.6302 \\
6 & 0.1218 & 70.201 & 4.2315 & 6.2656 & 3.0726 & 0.6000 & 3.020817 & 5.9384 & 2.2364 & 4.4335 \\
7 & 0.1293 & 70.302 & 3.8632 & 6.7274 & 3.1336 & 0.5540 & 2.861475 & 6.1315 & 2.1808 & 4.2460 \\
8 & 0.1365 & 70.190 & 3.8381 & 7.1869 & 3.2145 & 0.5430 & 2.753738 & 6.1440 & 2.1473 & 3.9826 \\
9 & 0.1436 & 69.738 & 3.9797 & 7.5942 & 3.4369 & 0.5772 & 2.760716 & 6.0275 & 2.1040 & 3.7820 \\
10 & 0.1505 & 69.498 & 3.9315 & 7.8861 & 3.6282 & 0.5946 & 2.759902 & 6.0042 & 2.0509 & 3.6463 \\
11 & 0.1569 & 69.413 & 3.8484 & 8.1204 & 3.7358 & 0.5904 & 2.718679 & 6.0230 & 2.0137 & 3.5362 \\
12 & 0.1630 & 69.326 & 3.8191 & 8.3340 & 3.8204 & 0.5901 & 2.684436 & 6.0119 & 1.9861 & 3.4281 \\
\hline
\end{tabular}

Source: Author's Computation

\section{Conclusion and Recommendations}

The result indicates that deposits, capital, spread, interest rate, leverage and state of the economy exact negative influence on banking sector index, while loans and assets have exact positive influence on same. This implies that banks' intermediation have a long run influence on banking sector index in Nigeria.

There is a need for economic managers and policymakers to realize the nature of the banking sector in Nigeria and should therefore, consider the required lag in any programme design to control their activities vis--vis the sector index position since only loans and advances had statistical and significant influence on the bank stock prices in both the short and long run.

Similarly, there is a need for DMBs managers to understand the influence of their activities on stock prices and use it as a gauge to measure investors' confidence and preference. This is essential in order to monitor investors' attitude towards their firm and put in place strategies and tactics that will continuously strengthen their market prices based on their current performance and future possibilities.

\section{References}

Adrian, T. and Shin, H. S. (2010). Liquidity and leverage. Journal of financial intermediation, 19(3):418-437.

Anwaar, M. (2016). Impact of firms performance on stock returns (evidence from listed companies of ftse-100 index london, uk). Global Journal of Management and Business Research.

Blau, B. M., Brough, T. J., and Griffith, T. G. (2017). Bank opacity and the efficiency of stock prices. Journal of Banking E Finance, 76:32-47. 
Francis, B. B., Hasan, I., Song, L., and Yeung, B. (2015). What determines bank-specific variations in bank stock returns? global evidence. Journal of Financial Intermediation, 24(3):312-324.

Gilchrist, S. and Zakrajšek, E. (2011). Monetary policy and credit supply shocks. IMF Economic Review, 59(2):195-232.

Ibrahim, M. H. (2006). Stock prices and bank loan dynamics in a developing country: The case of malaysia. Journal of Applied Economics, 9(1):7189.

Johansen, S. (1991). Estimation and hypothesis testing of cointegration vectors in gaussian vector autoregressive models. Econometrica: journal of the Econometric Society, pages 1551-1580.
Karkowska, R. (2013). The empirical analysis of dynamic relationship between financial intermediary connections and market return volatility. Available at SSRN 2351869.

Kühl, M. (2017). Bank capital, the state contingency of banks assets and its role for the transmission of shocks. Journal of Macroeconomics, 54:260-284.

Shabib-ul Hasan, S. F. and Muhammad, S. M. (2015). Stock returns indicators: Debt to equity, book to market, firm size and sales to price. Journal of Poverty, Investment and Development, 16(2):25-32.

Tennant, D. F. and Tracey, M. R. (2014). Financial intermediation and stock market volatility in a small bank-dominated economy. The Journal of Developing Areas, pages 73-95. 